\title{
Arytenoid chondritis in two calves
}

\author{
Mariana Oliveira Bonow ${ }^{1}$ Maira dos Santos Carneiro Lacerda ${ }^{2}$ Márcio Botelho de Castro $^{2}$ \\ Pedro Miguel Ocampos Pedroso² José Renato Junqueira Borges ${ }^{1}$ \\ Benito Soto-Blanco ${ }^{3}$ (D) Antonio Carlos Lopes Câmara ${ }^{1^{*}}$ iD
}

\begin{abstract}
${ }^{1}$ Hospital Escola de Grandes Animais, Faculdade de Agronomia e Medicina Veterinária (FAV), Universidade de Brasília (UNB), 70636-200, Brasília, DF, Brasil. E-mail: aclcamara@yahoo.com.br. "Corresponding author.

${ }^{2}$ Laboratório de Patologia Veterinária, Faculdade de Agronomia e Medicina Veterinária (FAV), Universidade de Brasília (UNB), Brasília, DF, Brasil.

${ }^{3}$ Departamento de Clínica e Cirurgia Veterinárias, Escola de Veterinária, Universidade Federal de Minas Gerais (UFMG), Belo Horizonte, MG, Brasil.

ABSTRACT: Although, calf diphtheria and necrotic laryngitis are common infections in the oral cavity's soft tissues, arytenoid chondritis is addressed as a serious but rarely diagnosed complication in cattle. This paper aimed to describe clinical, laboratory, imaging, and pathological findings in two calves with arytenoid chondritis. A 2-month-old Jersey calf and a 3-month-old Girolando calf presented 40-days history of respiratory distress. In the former, oral endoscopy revealed enlarged and immobile arytenoids with major involvement of the left arytenoid, causing severe distortion and partial obstruction of the rima glottidis. In the latter, latero-lateral radiography of the head revealed radiolucent areas and thickening at the level of the larynx to the dorsal trachea. Pathological examination of one calf showed neutrophilic multifocal inflammatory infiltrate and areas of necrosis in the cricoarytenoid cartilage, surrounded by abscessation. Definitive diagnosis of arytenoid chondritis in these two calves was established on the basis of clinical, laboratory, imaging (endoscopy and radiography), and pathological findings. Daily and careful observation of the herds and the use of ancillary diagnostic methods allowed the early diagnosis of the disease, and accurate diagnosis can improve prognosis and increase treatment success rate.

Key words: calf diphtheria, necrotic laryngitis, respiratory system, suppurative lesion.
\end{abstract}

\section{Condrite aritenóide em duas bezerras}

RESUMO: Embora a difteria em bezerros e a laringite necrótica sejam infecções comuns nos tecidos moles da cavidade oral, a condrite aritenoide é considerada uma complicação grave, mas raramente diagnosticada em bovinos. Este trabalho tem como objetivo descrever os achados clínicos, laboratoriais, de imagem e patológicos em duas bezerras apresentando condrite aritenoide. Uma bezerra Jersey de dois meses de idade e uma bezerra Girolando de três meses de idade apresentavam dificuldades respiratórias por 40 dias. Na primeira, a endoscopia oral revelou aritenoides aumentadas e imóveis, com grande envolvimento da aritenoide esquerda, causando distorção grave e obstrução parcial de rima glottidis. Na segunda, a radiografia látero-lateral da cabeça revelou áreas radioluscentes e espessamento ao nivel da laringe até a traqueia dorsal. O exame patológico de uma bezerra revelou infiltrado inflamatório multifocal neutrofilico e áreas de necrose na cartilagem cricoaritenóide, circundadas por abscessos. O diagnóstico definitivo de condrite aritenoide nessas duas bezerras foi estabelecido com base nos achados clínicos, laboratoriais, de imagem (endoscopia e radiografia) e patológicos. O monitoramento diário e minucioso dos rebanhos e o uso de métodos auxiliares de diagnóstico permitem o diagnóstico precoce da enfermidade, sendo que o diagnóstico preciso pode melhorar o prognóstico e aumentar a taxa de sucesso do tratamento.

Palavras-chave: difteria em bezerros, laringite necrótica, lesão supurativa, sistema respiratório.

Calf diphtheria is an infection of the soft tissue in the oral cavity following mucosal injury in calves aged 1-4 months. Affected animals usually have abscesses in the cheek region, mild salivation, and may refuse solid feed. Necrotic laryngitis defines the atypical form of the disease when the larynx becomes infected (PEEK et al., 2018). Additionally, a complication of necrotic laryngitis is called arytenoid chondritis, a condition characterized by chronic suppuration within the arytenoid cartilages of the larynx resulting in swelling and occlusion of the laryngeal lumen (GOULDING et al., 2003). The paucity of literature suggested that this complication in calves is underdiagnosed or under-reported (NICHOLS \& ANDERSON, 2009). Therefore, this paper aimed to describe clinical, laboratorial, imaging, and pathological findings in two calves with arytenoid chondritis.

Both owners stated that these calves were unique cases and that this disease was first observed 
on each farm. The first case was that of a 2-monthold Jersey calf presenting with a history of respiratory distress, rough coat, and retarded growth in the last 40 days. The owner treated the calf with anti-parasitic drugs (ivermectin and imidocarb), with no clinical improvement. Physical examination revealed fever $\left(40{ }^{\circ} \mathrm{C}, 104{ }^{\circ} \mathrm{F}\right)$, cyanotic mucosae, occasional dry coughs, tachycardia (160 beats/min), tachypnea (82 breaths/min) with mixed dyspnea, and head and neck extension with open-mouth breathing (Figure 1A). After surgical preparation, an emergency temporary tracheotomy and placement of a tracheotomy tube in the upper third of the neck was performed, resulting in immediate normopnea (Figure 1B). Oral endoscopy was performed after physical restraint revealing enlarged and immobile arytenoids with major involvement of the left arytenoid, causing severe distortion and partial obstruction of the rima glottidis. Vocal cords appeared normal. During maximal inspiration and expiration, the laryngeal lumen remained almost unchanged (Figure 1C and D).

Hematology revealed leukocytosis $(12,540 / \mu \mathrm{L}$; reference range: $4,000-12,000 / \mu \mathrm{L})$ with neutrophilia $(7,875 / \mu \mathrm{L}$; reference range: $600-4,000 /$ $\mu \mathrm{L})$, and serum biochemistry assay demonstrated hyperglobulinemia $(3.7 \mathrm{~g} / \mathrm{dL}$; reference range: 3.0 $3.48 \mathrm{~g} / \mathrm{dL}$ ). Urea, creatinine, total protein, albumin levels, fibrinogen, aspartate aminotransferase (AST), and gamma-glutamyl transferase activities were unremarkable. Based on clinical findings and endoscopic features, the presumptive diagnosis was bilateral arytenoid chondritis. Due to financial restraints, the owner declined hospitalization, and the calf was discharged to be treated in the farm with a broad spectrum antibiotic (enrofloxacin ${ }^{\mathrm{a}}: 5 \mathrm{mg} \cdot \mathrm{kg}^{-1}$, intramuscularly [IM], once a day [s.i.d.], for 14 days) and corticoid (dexamethasone ${ }^{\mathrm{b}}$ : $0.1 \mathrm{mg} \cdot \mathrm{kg}^{-1}$, IM, s.i.d., for five days) therapy, and daily tracheotomy tube cleaning. The owner when contacted by phone

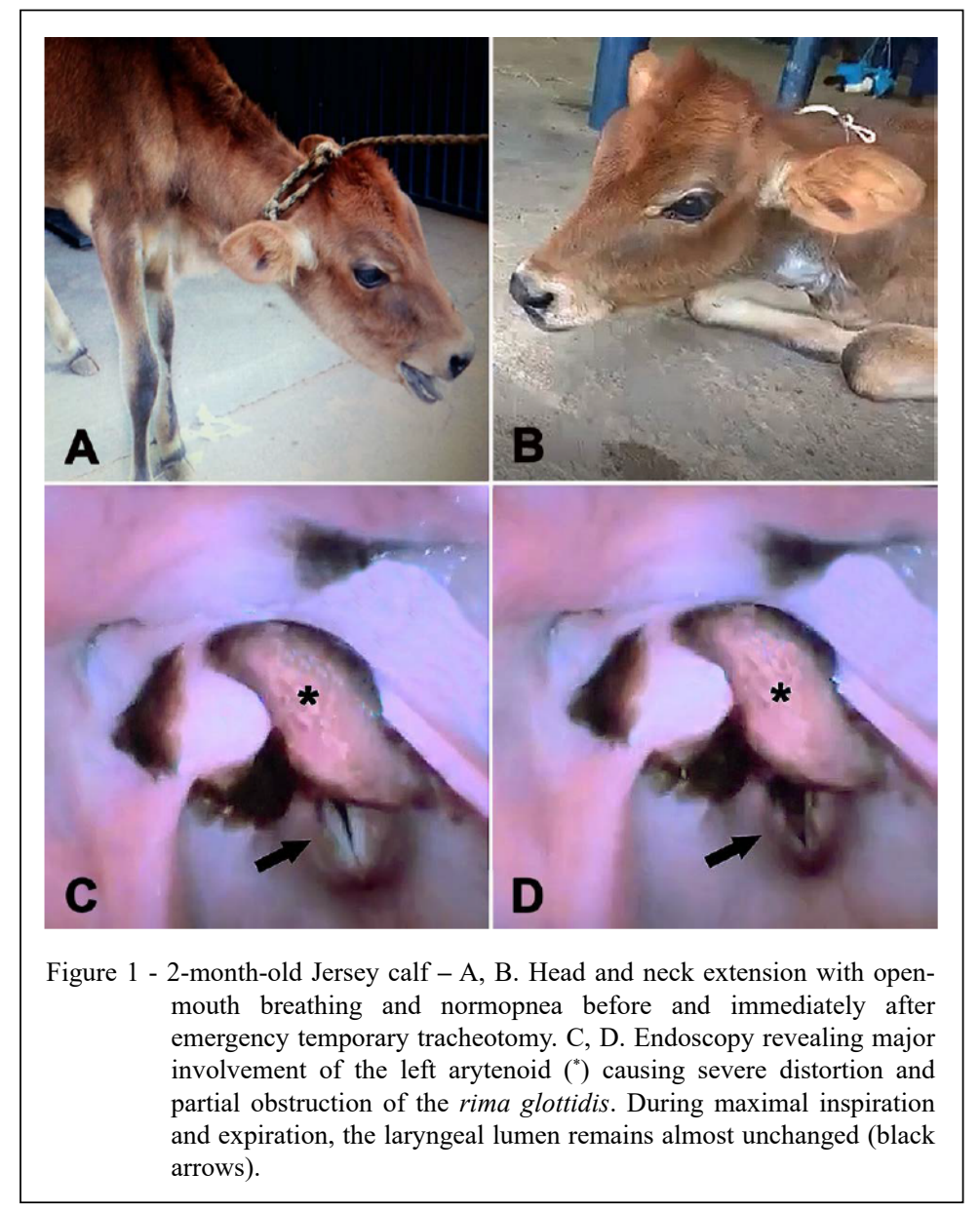

Ciência Rural, v.50, n.6, 2020. 
one month later, reported that the calf died 20 days after hospital discharge. No necropsy was performed.

The second case was that of a 3-monthold Girolando calf evaluated because of respiratory distress of 40 days' duration. The calf was treated at the farm by its owner with antibiotics, mucolytic (bromhexine), non-steroidal (flunixin meglumine), and steroidal (dexamethasone) anti-inflammatory drugs. The owner was unable to remember which antibiotics, the dosage and length of treatment. After this empirical treatment, the calf showed some clinical improvement, but soon respiratory signs relapsed. On hospital admission, physical evaluation revealed serous nasal discharge, tachycardia ( 92 beats/min), normal respiratory rate ( 24 breaths/min) with mixed dyspnea, and harsh sounds during tracheal auscultation suggesting laryngeal stridor. Hematological analysis presented absolute neutrophilia $(4,368 / \mu \mathrm{L}$; reference range: $600-4,000 / \mu \mathrm{L})$, and hyperfibrinogenemia (8 $\mathrm{g} / \mathrm{L}$; reference range: $1-7 \mathrm{~g} / \mathrm{L})$. Serum biochemistry profile showed hypoproteinemia $(6.5 \mathrm{~g} / \mathrm{dL}$; reference range: $6.7-7.4 \mathrm{~g} / \mathrm{dL})$ with hypoalbuminemia $(2.8$ $\mathrm{g} / \mathrm{dL}$; reference range: 3.03-3.55 g/dL). Urea, creatinine, globulin levels, and AST activity were unremarkable. Latero-lateral radiography of the head revealed radiolucent areas (gas and/or exudate collection) and thickening at the level of the larynx to the dorsal trachea (Figure 2A). The thoracic cavity appeared normal on radiographs. Combined clinical, and radiographic findings allowed the presumptive diagnosis of arytenoid chondritis.

During hospitalization, broad spectrum antibiotics (penicillin and streptomycin combination ${ }^{\mathrm{c}}$ : 40,000 IU. $\mathrm{kg}^{-1}$, IM, s.i.d., five days) and anti-inflammatory (meloxicam ${ }^{\mathrm{d}}$ : $0.5 \mathrm{mg} \cdot \mathrm{kg}^{-1}$, I.M., s.i.d., five days) therapy was initiated. Two days later, respiratory distress worsened, and a temporary tracheotomy was performed as described earlier; immediate relief from dyspnea was evident. Approximately $24 \mathrm{~h}$ post-surgery, the calf presented apathy, recumbence, and bilateral abdominal tympany. Therefore, a left flank exploratory laparotomy was performed, revealing abomasal perforation and diffuse peritonitis. The calf was humanely euthanized, and necropsy was conducted.

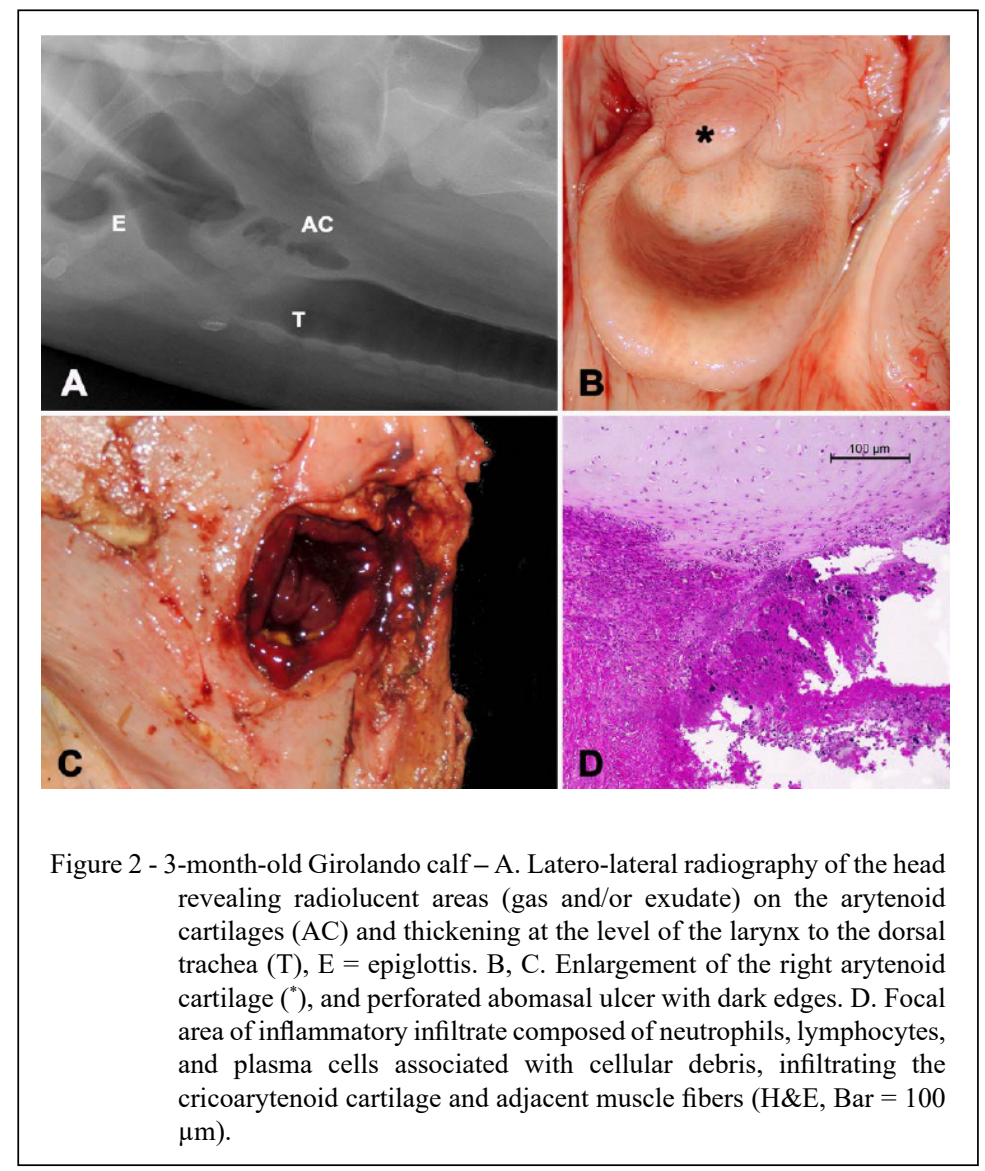

Ciência Rural, v.50, n.6, 2020. 
Main gross findings included accumulation of fetid and blackish liquid in the peritoneal cavity, associated with fibrin clots adhered to the organs' serous surfaces and free in the cavity. Abomasum presented diffuse reddish and edematous mucosa with a perforated ulcer with dark edges measuring $3 \mathrm{~cm}$ in diameter (Figure 2C). On the larynx there was enlargement of the right arytenoid and cricoid cartilages (Figure 2B), with yellow purulent discharge after cutting. An aseptic sample from the pus was referred for microbiological assay, which yielded mixed bacterial growth (Escherichia coli, Klebisiella sp., and Pasteurella sp.). Histologically, the cricoarytenoid cartilage presented mainly neutrophilic multifocal inflammatory infiltrate and areas of necrosis, surrounded by abscessation (Figure 2D).

Although, calf diphtheria and necrotic laryngitis are considered common infections of the oral cavity's soft tissues (PEEK et al., 2018), arytenoid chondritis is addressed as a serious and rarely diagnosed complication in cattle (ANDERSON, 2009). Clinical signs of calf diphtheria depend upon the site of infection and the lesions on the surrounding areas. They may vary from abscesses on the cheek region, frothy salivation, and hyporexia (PEEK et al., 2018) to anorexia, fever, halitosis, severe inspiratory or mixed dyspnea, laryngeal stridor, head and neck extension, and open-mouth breathing, when arytenoid chondritis occur (GOULDING et al., 2003; NICHOLS \& ANDERSON, 2009).

Neutrophilic leukocytosis, absolute neutrophilia, hyperfibrinogenemia, and hyperglobulinemia are consistent with bacterial infection. Hypoalbuminemia detected in the second calf possibly occurred because albumin being a negative acute-phase protein, decreases in concentration following malnutrition and/or laryngeal pain impairing swallowing (PEEK et al., 2018). Endoscopic features of arytenoid chondritis in farm animals are scarce, and most common changes include enlarged and immobile arytenoids, nasopharynx and epiglottis inflammation, and distortion and obstruction of the rima glottidis (LANE et al., 1987; NICHOLS \& ANDERSON, 2009), as observed herein. Imaging ancillary tests, such as radiography and endoscopy, play an important role in revealing the severity of the disease, and may also be used to evaluate treatment response (ANDERSON, 2009).

Fusobacterium necrophorum is associated with numerous necrotic disease conditions generally termed 'necrobacillosis' that may involve any part of the body, but is most common in the liver, feet, mammary gland, and oropharyngeal mucosa (NAGARAJA et al., 2005). Although, F. necrophorum is the one usually linked to calf diphtheria and its complications (ANDERSON, 2009; PEEK et al., 2018), several other microorganisms may be involved, since mixed bacterial growth of gram-positive and gram-negative bacteria was reported in $>80 \%$ of the cases in Icelandic sheep (SIGUROARDOTTIR et al., 2016). Similar observations were made in the Girolando calf. The most commonly isolated bacteria include Fusobacterium spp., Trueperella pyogenes, Streptococcus spp., Bacteroides spp., Pasteurella spp., and Escherichia coli (LANE et al., 1987; SIGUROARDOTTIR et al., 2016). There are sporadic reports of the involvement of other bacterial species such as laryngeal abscessation due to Mannheimia haemolytica in an alpaca (DWAN et al., 2008), and necrotic pharyngitis by Mycoplasma bovis in an American bison (DYER et al., 2013).

Pathological features of arytenoid chondritis in the Girolando calf were similar to those previously reported (LANE et al., 1987; SIGUROARDOTTIR et al., 2016). Additionally, this calf presented a perforated abomasal ulcer and diffuse peritonitis. Factors related to abomasal ulcers in calves during the transitional phase include stress, hair balls, mineral deficiencies, and Clostridium perfrigens type A and D infections (MARSHALL, 2009). In our case, the stress caused by chronic difficulty in breathing and abuse of anti-inflammatory drugs by the owner may have played an important role in the pathogenesis of abomasal ulceration.

Arytenoid chondritis is a difficult condition to treat medically (LANE et al., 1987; NICHOLS \& ANDERSON, 2009). When medical treatment fails to resolve respiratory distress, surgical options include permanent tracheostomy (GOULDING et al., 2003), tracheolaryngostomy, or arytenoidectomy (ANDERSON, 2009). Definitive diagnosis of arytenoid chondritis in these two calves was established based on clinical, laboratory, imaging (endoscopy and radiography), and pathological findings. Daily and careful observation of the herds and the use of ancillary diagnostic methods allow for the early diagnosis of arytenoid chondritis. Accurate diagnosis can improve prognosis and increase treatment success rate.

\section{ACKNOWLEDGEMENTS}

This work was partially financed by the Coordenação de Aperfeiçoamento de Pessoal de Nível Superior (CAPES), Brasil - Finance code 001. 


\section{BIOETHICS \\ AND \\ COMMITTEE APPROVAL \\ BIOSSECURITY}

We, authors of the article titled "Arytenoid chondritis in two calves", declare, for all due purposes, that the project that gave rise to the present data of the same has not been submitted for evaluation to the Ethics Committee of the Universidade de Brasília, but we are aware of the content of the Brazilian resolutions of the National Council for Control of Animal Experimentation - CONCEA "http://www.mct.gov.br/index.php/ content/view/310553.html" if it involves animals.

Thus, the authors assume full responsibility for the presented data and are available for possible questions, should they be required by the competent authorities.

\section{DECLARATION OF CONFLICT OF INTEREST}

The authors declare no conflict of interest. The founding sponsors had no role in the design of the study; in the collection, analyses, or interpretation of data; in the writing of the manuscript, and in the decision to publish the results.

\section{AUTHORS' CONTRIBUTIONS}

The authors contributed equally to the manuscript.

\section{SOURCES OF MANUFACTURES}

${ }^{a}$ Floxiclin - Biofarm Química e Farmacêutica Ltda., Jaboticabal, São Paulo, Brazil.

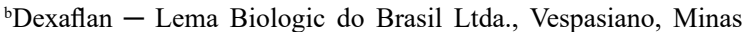
Gerais, Brazil.

${ }^{\mathrm{c} M e g a c i l i n}$ Superplus - União Química Farmacêutica, EmbuGuaçu, São Paulo, Brazil.

${ }^{\mathrm{d}}$ Maxicam 2\% - Ourofino Saúde Animal Ltda., Cravinho, São Paulo, Brazil.

\section{REFERENCES}

ANDERSON, D.E. Surgery of the larynx and trachea. In: ANDERSON, D.E.; RINGS, D.M. (Eds.). Current Veterinary Therapy: Food animal practice. $5^{\text {th }}$ ed. Philadelphia: W.B. Saunders; 2009. p.207-209.
DYER, N. et al. Necrotic pharyngitis associated with Mycoplasma bovis infection in American bison (Bison bison). Journal of Veterinary Diagnostic Investigation, v.25, p.301303, 2013. Available from: <https://www.ncbi.nlm.nih.gov/ pubmed/23512925>. Accessed: Oct. 21, 2019.

DWAN, L.W. et al. Laryngeal abscessation due to Mannheimia haemolytica in an alpaca (Vicugna pacos) cria. Veterinary Record, v.163, p.124-125, 2008. Available from: <http://veterinaryrecord. bmj.com/cgi/pmidlookup?view=long\&pmid=18660524>. Accessed: Jul. 18, 2019.

GOULDING, R. et al. Use of a permanent tracheostomy to treat laryngeal chondritis and stenosis in a heifer. Veterinary Record, v.152, p.809-811, 2003. Available from: $<$ https://veterinaryrecord. bmj.com/content/152/26/809>. Accessed: Jul. 18, 2019.

LANE, J.G. et al. Laryngeal chondritis in Texel sheep. Veterinary Record, v.121, p.81-84, 1987. Available from: <https:// veterinaryrecord.bmj.com/content/121/4/81>. Accessed: Aug. 26,2019

MARSHALL, T.S. Abomasal ulceration and tympany of calves. Veterinary Clinics of North America: Food Animal Practice, v.25, p.209-220, 2009. Available from: <https://www. sciencedirect.com/science/article/pii/S0749072008000935>. Accessed: Nov. 14, 2019.

NAGARAJA, T.G. Fusobacterium necrophorum infections in animals: pathogenesis and pathogenic mechanisms. Anaerobe, v.11, p.239-246, 2005. Available from: <https://www.ncbi.nlm.nih. gov/pubmed/16701574>. Accessed: Oct. 21, 2019.

NICHOLS, S.; ANDERSON, D.E. Subtotal or partial unilateral arytenoidectomy for treatment of arytenoid chondritis in five calves. Journal of the American Veterinary Medical Association, v.235, p.420-425, 2009. Available from: <https:// www.ncbi.nlm.nih.gov/pubmed/19681726 >. Accessed: Jul. $24,2019$.

PEEK, S.F.; OLLIVETT, T.L.; DIVERS, T.J. Respiratory diseases. In: PEEK, S.F.; DIVERS, T.J. (Eds). Rebhun's Diseases of Dairy Cattle. $3^{\text {rd }}$ ed. St. Louis: Elsevier; 2018. p.94-167.

SIGUROARDOTTIR, O.G. et al. Laryngeal chondritis in sheep in Iceland. Journal of Comparative Pathology, v.155, p.310313, 2016. Available from: <https://www.ncbi.nlm.nih.gov/ pubmed/27658578>. Accessed: Jul. 18, 2019. 